\title{
The impact of the Green Revolution on indigenous crops of India
}

\author{
Ann Raeboline Lincy Eliazer Nelson, Kavitha Ravichandran* and Usha Antony
}

\begin{abstract}
The Green Revolution in India was initiated in the 1960s by introducing high-yielding varieties of rice and wheat to increase food production in order to alleviate hunger and poverty. Post-Green Revolution, the production of wheat and rice doubled due to initiatives of the government, but the production of other food crops such as indigenous rice varieties and millets declined. This led to the loss of distinct indigenous crops from cultivation and also caused extinction. This review deals with the impacts the Green Revolution had on the production of indigenous crops, its effects on society, environment, nutrition intake, and per capita availability of foods, and also the methods that can be implemented to revive the indigenous crops back into cultivation and carry the knowledge to the future generation forward.
\end{abstract}

Keywords: Green Revolution, India, Farmers, Indigenous varieties, Rice, Millets

\section{Introduction}

India holds the second-largest agricultural land in the world, with 20 agro-climatic regions and 157.35 million hectares of land under cultivation [1]. Thus, agriculture plays a vital role with $58 \%$ of rural households depending on it even though India is no longer an agrarian economy. A report by the Department of Agriculture, Cooperation and Farmers Welfare estimates that the food grain production in India will be 279.51 million tonnes during the 2017-2018 crop year. Although India is self-sufficient in food production, its food production between 1947 and 1960 was so bad that there were risks for the occurrence of famine. Therefore, the Green Revolution was initiated in the 1960s in order to increase food production, alleviate extreme poverty and malnourishment in the country, and to feed millions. In spite of these measures, India has one quarter of the hungry population of the world with 195.9 million undernourished people lacking sufficient food to meet their daily nutritional requirements; $58.4 \%$ of children under the age of five suffer from anemia, while in the age group of $15-49,53 \%$ of women and $22.7 \%$ of men are anemic; $23 \%$ of women and $20 \%$ of men are thin, and $21 \%$ of women and $19 \%$ of men are obese $[2,3]$.

\footnotetext{
* Correspondence: kavisri9@gmail.com

Centre for Food Technology, Department of Biotechnology, Alagappa

College of Technology, Anna University, Chennai 600025, Tamil Nadu, India
}

The major crops cultivated in the era preceding the Green Revolution were rice, millets, sorghum, wheat, maize, and barley $[4,5]$, and the production of rice and millets were higher than the production of wheat, barley, and maize combined all together. But the production of millets has gone down, and the crops that were once consumed in every household became a fodder crop in just a few decades after the Green Revolution. Meanwhile, a number of traditional rice varieties consumed prior to the Green Revolution have become nonexistent, and the availability of local rice varieties have decreased to 7000 and not all of these varieties are under cultivation. Thus, India has lost more than 1 lakh varieties of indigenous rice after the 1970s that took several thousand years to evolve [6]. This loss of species is mainly due to the focus given to the production of subsidized high-yielding hybrid crops and the emphasis of monoculture by the government.

The measures initiated by the government increased the production of rice, wheat, pulses, and other crops leading to the self-sufficiency of food in the country. But it also destroyed the diversified gene pool available. The productivity of the crops was increased by the use of fertilizers, pesticides, and groundwater resources. However, mismanagement and overuse of chemical fertilizers, pesticide, and lack of crop rotation caused the land to become infertile, and loss of groundwater became a 
common occurrence in agricultural areas. These impacts made the farmers even more miserable, due to the increased expenditure spend on the cultivation of crops to overcome these shortcomings.

This review focuses on the genesis of the Green Revolution and its impacts and effects on the production of indigenous crops, society, environment, nutrition intake, and per capita availability of foods. Furthermore, the methods that can be implemented to revive the indigenous crops back into cultivation and carry the knowledge to the future generation forward is also discussed in detail.

\section{Green Revolution}

The word "Green Revolution" was coined by William S. Gaud of United States Agency for International Development (USAID) in 1968, for the introduction of new technology and policies implemented in the developing nations with aids from industrialized nations between the 1940s and the 1960s to increase the production and yield of food crops [7, 8]. Many high-yielding varieties (HYVs) were introduced as part of the Green Revolution to increase agricultural productivity. These genetically improved varieties of wheat and rice were developed by the International Maize and Wheat Improvement Centre (CIMMYT), Mexico, and the International Rice Research Institute (IRRI), Philippines, respectively. The HYVs had $20 \%$ more grain than its earlier cultivars and were more responsive to the nitrogen fertilizers. The yield potential doubled due to the incorporation of several traits and specific genes for short stature in HYVs $[9,10]$. The incorporation of the gene responsible for photoinsensitivity in rice and wheat enabled cultivation possible throughout the year; regardless of day length of the region, it was cultivated [11, 12]. Furthermore, the reduced cropping period increased the cropping intensity to 2-3 crops per year. For instance, the newly introduced IR- 8 took 130 days to mature, and the varieties later developed such as IR-72 took 100 days to mature while the traditional rice cultivars took 150 to 180 days to mature [9]. The period between 1960 and 1985 saw the doubling of yield per hectare, total productivity, and total food production in developing countries [7]. Accordingly, the global production of cereals increased by $174 \%$ between 1950 and 1990 while the global population increased by $110 \%$ [13]. The increased production of cereals enabled the nations to feed their growing population and averting the Malthusian scenario predicted in the 1960s $[14,15]$.

When India became independent in 1947, $90 \%$ of its population lived in 600,000 villages depending mainly on agriculture for their subsistence. For a few centuries, Indian agriculture remained unchanged without any technological changes in agricultural practices [16]. The technologies employed in agriculture were the seeds cultivated by the farmers having a genetic makeup that went back thousands of years and the involvement of wooden plows, waterwheels, and bullock carts, along with the agricultural practices driven by the energy provided by animals and humans. Therefore, failure of the agriculture sector to meet the demands of India after 1947 until 1965 reflected negatively in the growth of the industrial sector. The lack of proper technological change and land reforms combined with droughts brought India to the verge of massive famine in the mid1960s. However, this situation was averted by massive shipments of subsidized food grains mainly wheat by the USA. This measure, in turn, depleted the reserves of the nation. So, in order to save the reserves and to increase the productivity of cereals, all the stakeholders and donor agencies decided to induce changes in agricultural technology and practices [17-20].

The HYVs of rice suitable for cultivation in tropical climatic conditions of South Asia were developed by the IRRI in the 1960s, based on the genetic materials drawn from China, Taiwan, and Indonesia. The most famous rice variety introduced as a part of the Green Revolution in India was IR-8. It was developed based on experience in developing the Norin variety of Japan and Ponlai variety of Taiwan. IR-8 was short, stiff strawed, and highly responsive to the fertilizers. In India, the yield of IR-8 was $5-10 \mathrm{t}$ per hectare $[8,21]$.

Semi-dwarf wheat varieties developed in Japan in the 1800s were used to develop the HYVs of wheat. The two varieties namely Akakomugi and Daruma of Japan were used for the international breeding programs of wheat [22]. Norin 10 was developed by crossing Daruma and native American varieties. In 1948, the US scientists crossed Norin 10 with Brevor, a native American variety to give rise to Norin-Brevor cross. This cross was taken to CIMMYT, Mexico, in 1954; there several HYVs of wheat were developed by Norman Borlaug and others, and these varieties were transferred to India in the 1960s $[8,21]$.

The HYVs of wheat and rice were tested by the Indian scientists in 1962 and 1964 respectively. Later, these tested varieties were introduced throughout the nation during the crop year of 1965-1966 [20, 23]. Thus, the Green Revolution involved the use of HYVs of wheat and rice and adoption of new agricultural practices involving the use of chemical fertilizers, pesticides, tractors, controlled water supply to crops, mechanical threshers, and pumps $[19,24]$. The combination of these techniques was commonly termed as "high-yielding variety technology (HYVT)." This technology was responsible for the increased growth rate of food-grain output from $2.4 \%$ per annum before 1965 to $3.5 \%$ after 1965 . Initially, the major increase in food production was due to increased production of wheat that increased from 50 
million tonnes in 1950 to 79 million tonnes in 1964 and later to 95.1 million tonnes in 1968 [24]. Since then, importing food grains has declined considerably.

The success of the Green Revolution in India in terms of crop yield is attributed to the government of India, international agricultural research institutions (IRRI and CIMMYT), multilateral and bilateral donor agencies (Ford Foundation, Rockefeller Foundation, and USAID), and the farmers. The Ministry of Food and Agriculture and the Indian Council of Agricultural Research (ICAR) meticulously executed the smooth transmission and distribution of new technology [19, 25].

\section{Ecological and societal impacts}

In the past, Indian farms were small plots of land protected by windbreaks and tree cover. For centuries, the farmers employed several methods of organic husbandry, crop rotation, and leaving fields fallow for long periods of time in order to allow the soil to retain its nutrients. These practices lowered the demand on the land and maintained the equilibrium of soil [26, 27].

Though the high-yielding monohybrid crops were introduced as a part of Green Revolution, the major problem with indigenous seeds was not the fact that they were not high yielding, but their inherent inability to withstand the chemical fertilizers used. On the contrary, new varieties were created to produce higher yields in conjunction with the use of chemical fertilizers and very intense irrigation $[24,28]$. The amount of chemical fertilizers used post-advent of the Green Revolution was quite high, and the increase in the consumption of chemical fertilizers for the cultivation of crop can be seen in Fig. 1, which elucidates the steep increase in the use of fertilizers since 1981-1982. The overuse of chemical fertilizers to get high yield causes physical and chemical degradation of the soil by altering the natural microflora and increasing the alkalinity and salinity of the soil [30]. The excessive use of groundwater for irrigation depleted the water table in many parts of the country.

The newly introduced high-yielding seeds had a very narrow genetic base as compared to the indigenous species. The sole cultivation of monohybrid crops in the field by the farmers caused the removal of several indigenous species from cultivation [19, 27]. Besides, the instability of the acquired traits in modern varieties such as high-yielding rice varieties, hybrids, and genetically engineered rice and the associated environmental degradation with its cultivation has caused a regular decline in yields and quality of food grains produced. For example, in the 1960s, the high yield was recorded in the newly introduced varieties IR-8 and ADT-27 in the Cauvery Delta, Tamil Nadu, and it was publicized as a conquest of high-yielding varieties over the low-yielding indigenous varieties. Although the yields were high initially, later it declined and disappeared from cultivation within few years of its introduction [31].

The major ecological and societal impacts of the Green Revolution can be summarized as follows: (1) loss of landraces that were indigenous to our country, (2) the loss of soil nutrients making it unproductive, (3) excessive use of pesticides increases the presence of its residues in foods and environment [24, 32-34], (4) the farmers shift to unsustainable practices to obtain more

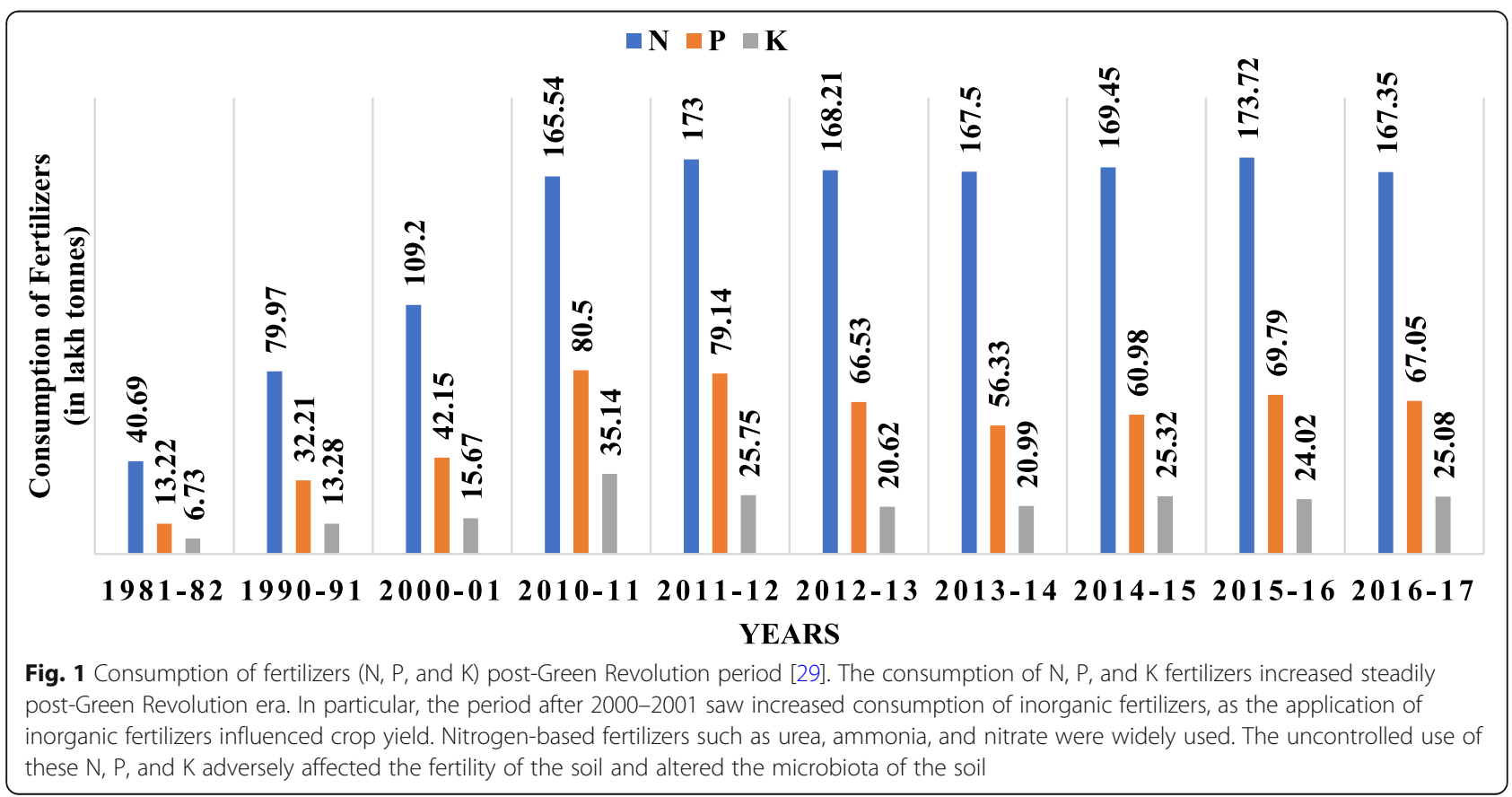


yield, (5) increased rates of suicide among farmers, (6) unable to withstand the increasing expenses for farming and debts small farmers sold their lands to large commercial farmers, and (7) unable to withstand the food inflation and economic crisis the farmers left farming resorting to other occupation.

\section{Impact on the cultivation of food grains}

Post-Green Revolution, the area under cultivation increased from 97.32 million hectares in 1950 to 126.04 million hectares in 2014 [1]. The area under cultivation of coarse cereals decreased drastically from 37.67 million hectares to 25.67 million hectares since the 1950s. Likewise, the area under cultivation of sorghum decreased from 15.57 million hectares to 5.82 million hectares and that of pearl millet decreased from 9.02 million hectares to 7.89 million hectares [1]. But the area under the cultivation of rice, wheat, maize, and pulses increased from 30.81 million hectares to 43.95 million hectares, 9.75 million hectares to 31.19 million hectares, 3.18 million hectares to 9.43 million hectares, and 19.09 million hectares to 25.23 million hectares respectively [1]. The trends in the production of food grains influenced the availability and consumption of food grains in rural and urban households (Fig. 2).

\section{Impact on the availability and consumption of food grains}

The per capita net availability of food grains increased over the years. The per capita net availability of rice increased from $58.0 \mathrm{~kg} /$ year in 1951 to $69.3 \mathrm{~kg} /$ year in
2017. The per capita net availability of rice was an alltime high in 1961. Similarly, the per capita net availability of wheat increased from $24.0 \mathrm{~kg} /$ year in 1951 to 70.1 $\mathrm{kg} /$ year in 2017. However, the per capita net availability of other cereal grains such as millets and pulses decreased over the years. This led to the change in the consumption pattern over the years and the shift in focus from the minor cereals and pulses to the major cereals, rice and wheat (Fig. 3).

The trends in percentage composition of consumer expenditure since 1987 (Table 1) reveal that cereals played a major role in both rural and urban households in 1987. But the composition of cereals on consumer expenditure decreased from 26.3 to $12.0 \%$ in rural households whereas the percentage in urban households dipped to 7.3 from $15.0 \%$. The consumption of cereal substitutes such as coarse cereals and millets was stationary at $0.1 \%$ in rural households since 1987 but dipped to zero in urban areas after 1993-1994, only to be revived back to $0.1 \%$ in 2011-2012. Similarly, the consumption of pulses declined in both urban and rural households. Furthermore, it also indicates the shift in expenditure spend on cereals to non-food items in both rural and urban households with years; this may be attributed to the change in lifestyle.

\section{Impact on nutrition}

Millets are rich in protein, vitamins, and minerals. Singh et al. [36] report proteins in millets as a good source of essential amino acids, including histidine, isoleucine,

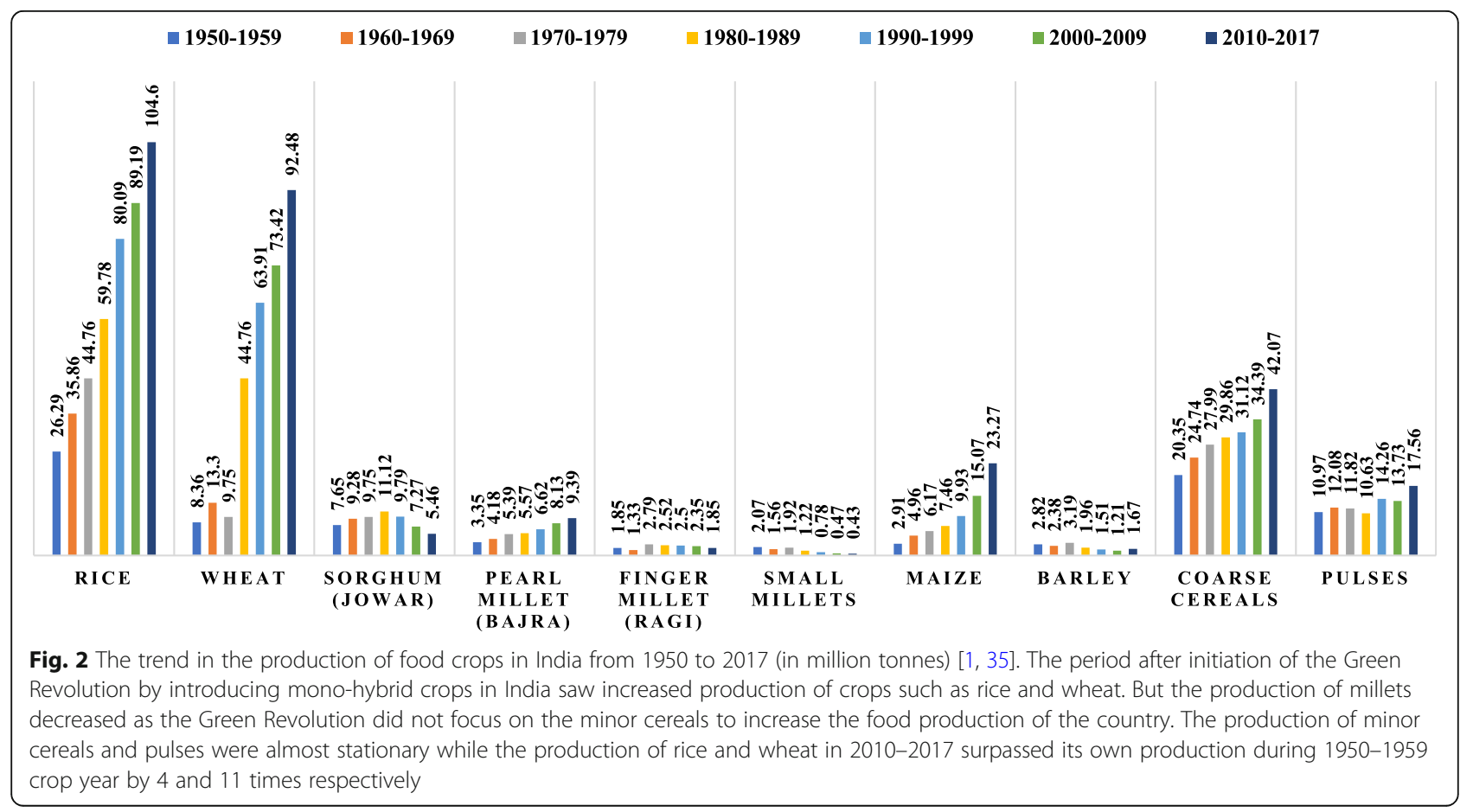




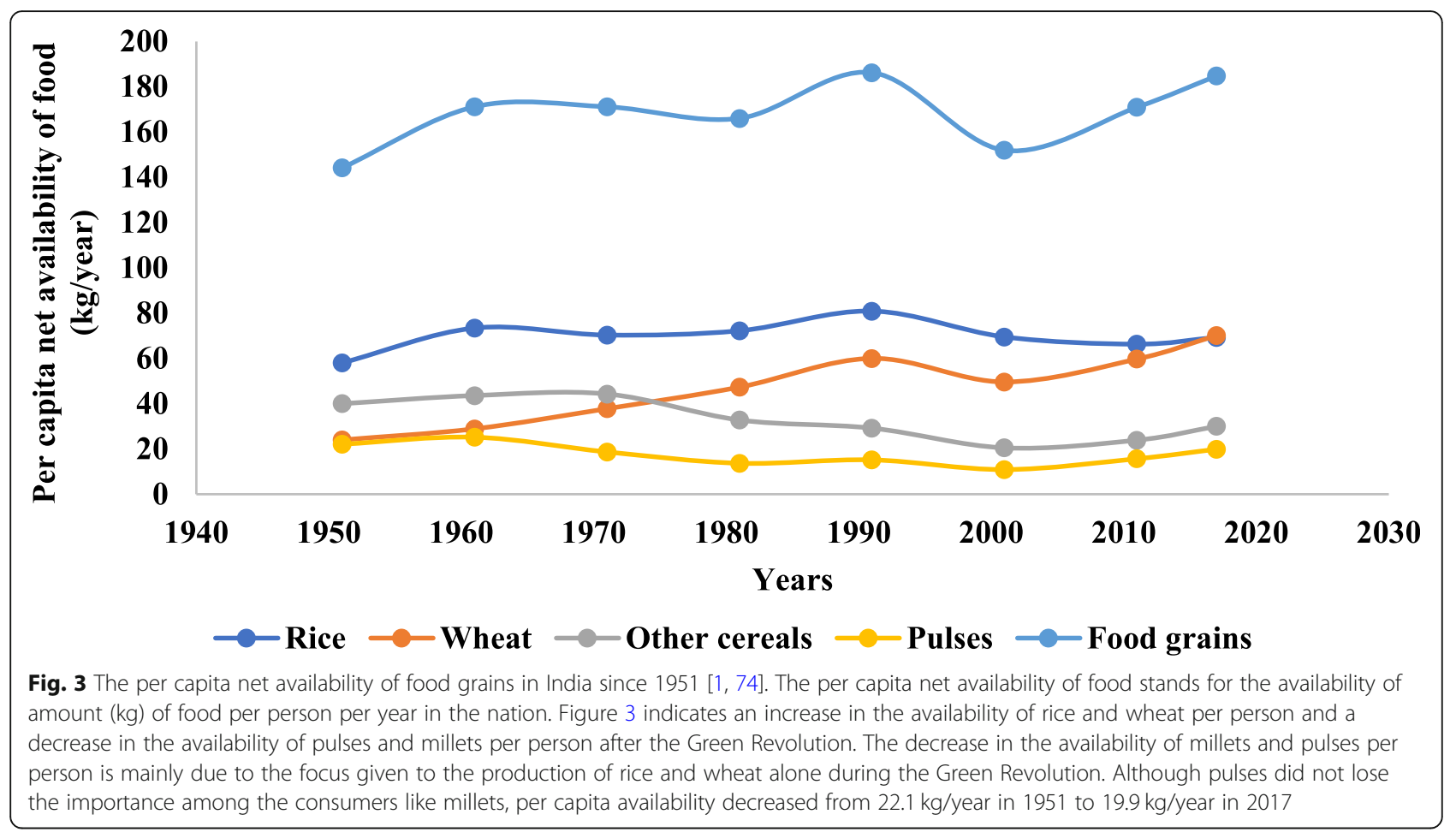

leucine, methionine, phenylalanine, tryptophan, and valine, lacking lysine and threonine. They are also rich in methionine and cysteine that contains sulfur. Furthermore, millets are also a very good source of dietary minerals such as phosphorus, calcium, iron, and zinc, especially finger millet which contains nine- to tenfold higher calcium than others.

Rough rice contains more amount of riboflavin, thiamine, niacin, calcium, phosphorus, iron, and zinc than the milled (polished) rice (Table 2). The milled rice loses its nutrients during polishing, and the nutrient content present in it varies with the degree of polishing.
Brown rice undergoes minimal processing, so it retains nutrients such as thiamine, niacin, riboflavin, calcium, phosphorus, and iron. Barnyard millet has the highest amount of crude fiber among the cereals. Furthermore, the colored rice varieties such as red rice and black rice are also a good source of protein and fat.

The consumption of major cereals such as rice and wheat along with pulses and decrease in the addition of coarse cereals, foods of animal origin, and fruits and vegetables in the diet lead to deficiency of micronutrients such as iron, zinc, calcium, vitamin A, folate, and riboflavin among the population causing anemia, keratomalacia,

Table 1 Trends in percentage composition of consumer expenditure since 1987-1988 [1]

\begin{tabular}{|c|c|c|c|c|c|c|c|c|c|c|c|c|}
\hline \multirow[t]{2}{*}{ Year/group } & $\begin{array}{l}1987- \\
1988\end{array}$ & $\begin{array}{l}1993- \\
1994\end{array}$ & $\begin{array}{l}1999- \\
2000\end{array}$ & $\begin{array}{l}2004- \\
2005\end{array}$ & $\begin{array}{l}2009- \\
2010\end{array}$ & $\begin{array}{l}2011- \\
2012\end{array}$ & $\begin{array}{l}1987- \\
1988\end{array}$ & $\begin{array}{l}1993- \\
1994\end{array}$ & $\begin{array}{l}1999- \\
2000\end{array}$ & $\begin{array}{l}2004- \\
2005\end{array}$ & $\begin{array}{l}2009- \\
2010\end{array}$ & $\begin{array}{l}2011- \\
2012\end{array}$ \\
\hline & \multicolumn{6}{|l|}{ Rural } & \multicolumn{6}{|l|}{ Urban } \\
\hline Cereals & 26.3 & 24.2 & 22.2 & 18.0 & 15.6 & 12.0 & 15.0 & 14.0 & 12.4 & 10.1 & 9.1 & 7.3 \\
\hline Gram & 0.2 & 0.2 & 0.1 & 0.1 & 0.2 & 0.2 & 0.2 & 0.2 & 0.1 & 0.1 & 0.1 & 0.1 \\
\hline Cereal substitutes & 0.1 & 0.1 & 0.1 & 0.1 & 0.1 & 0.1 & 0.1 & 0.1 & 0.0 & 0.0 & 0.0 & 0.1 \\
\hline Pulses and products & 4.0 & 3.8 & 3.8 & 3.1 & 3.7 & 3.1 & 3.4 & 3.0 & 2.8 & 2.1 & 2.7 & 2.1 \\
\hline Milk and products & 8.6 & 9.5 & 8.8 & 8.5 & 8.6 & 9.1 & 9.5 & 9.8 & 8.7 & 7.9 & 7.8 & 7.8 \\
\hline Edible oil & 5.0 & 4.4 & 3.7 & 4.6 & 3.7 & 3.8 & 5.3 & 4.4 & 3.1 & 3.5 & 2.6 & 2.7 \\
\hline Egg, fish, and meat & 3.3 & 3.3 & 3.3 & 3.3 & 3.5 & 3.6 & 3.6 & 3.4 & 3.1 & 2.7 & 2.7 & 2.8 \\
\hline Vegetables & 5.2 & 6.0 & 6.2 & 6.1 & 6.2 & 4.8 & 5.3 & 5.5 & 5.1 & 4.5 & 4.3 & 3.4 \\
\hline Fruits and nuts & 1.6 & 1.7 & 1.7 & 1.9 & 1.6 & 1.9 & 2.5 & 2.7 & 2.4 & 2.2 & 2.1 & 2.3 \\
\hline Total, food & 64.0 & 63.2 & 59.4 & 55.0 & 53.6 & 48.6 & 56.4 & 54.7 & 48.1 & 42.5 & 40.7 & 38.5 \\
\hline Total, non-food & 36.0 & 36.8 & 40.6 & 45.0 & 46.4 & 51.4 & 43.6 & 45.3 & 51.9 & 57.5 & 59.3 & 61.5 \\
\hline
\end{tabular}




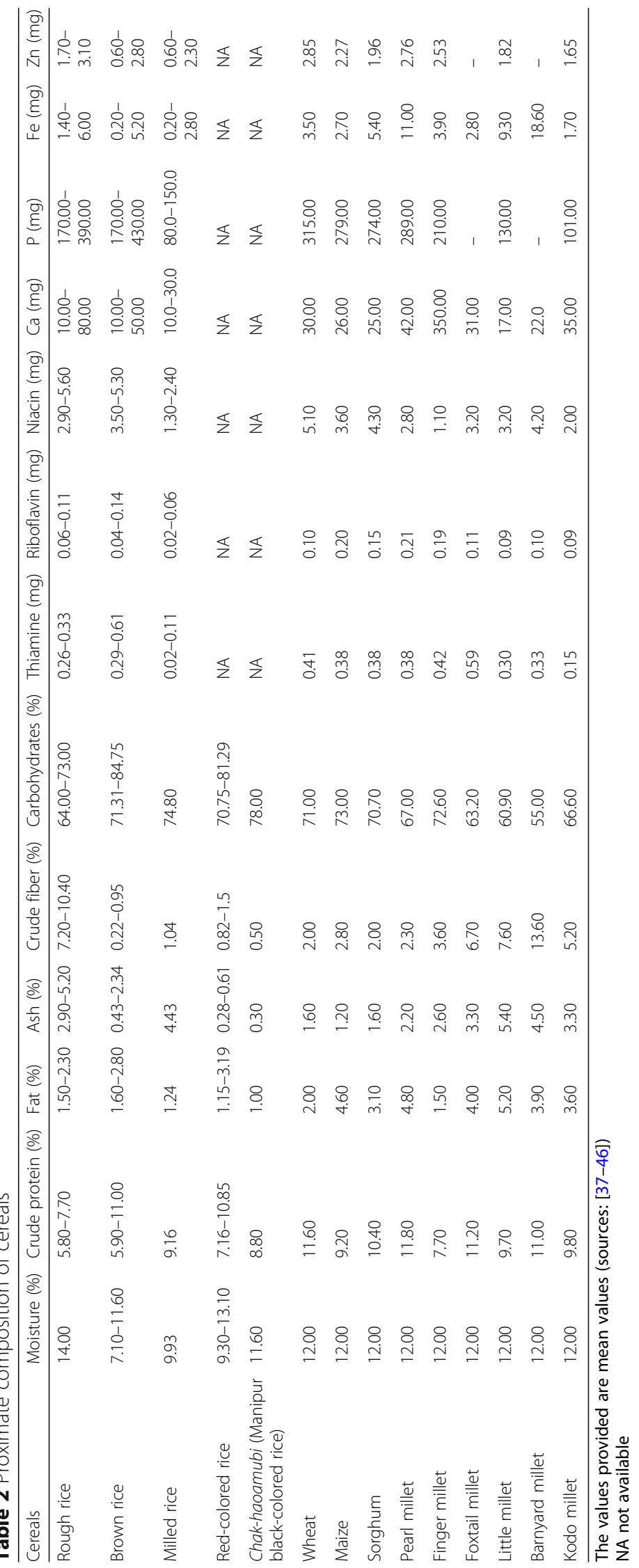


blindness, and infertility in severe cases. Surveys conducted by the National Nutrition Monitoring Bureau and others also conclude the same that the Indian diets based on cereal pulse are qualitatively deficient in micronutrients [47].

Anemia due to iron deficiency is the most serious health issue among all other deficiency disorders. A report by the Indian Council of Medical Research (ICMR) states anemia due to iron deficiency may cause an impaired immune system (resistance to fight against infections), reduced reproductive health and related problems such as premature birth, low birth weight, and perinatal mortality, and affect cognitive and motor development and physical performance. According to the Indian National Science Academy (INSA), malnutrition and deficiency of micronutrients in India, particularly among women, children, and adolescents, need immediate attention [48].

\section{Indigenous crops}

The indigenous crops are popular and culturally known native varieties. Every region of the world has unique traditional foods that are widely consumed by a group of people, or by a particular community, for instance, consumption of black walnut, wild rice, pecan, palmetto berries, squash, succotash, sofkee, and fajitas by the native American tribes; Kyo-no-dento-yasai, ishiru, yamato persimmon, and katsura-uri by the Japanese; and kolo, kita, dabo, beso, genfo, chuko, tihlo, shorba, kinche, and injera by the Ethiopians [49-53]. The traditional foods and cereal-based products that once occupied a part of the regular Indian diet are lost in time due to the emphasis on mono-cropping post-Green Revolution. The indigenous crops of India include several varieties of rice such as colored rice, aromatic rice, and medicinal rice varieties: millets, wheat, barley, and maize. The indigenous varieties of rice and millets are resistant to drought, salinity, and floods. For example, Dharical, Dular, and Tilak Kacheri of Eastern India are adaptable to different topology, climate, and soils [54]. The coarse cereals include sorghum, pearl millet, maize, barley, finger millet, and small millets like barnyard millet, foxtail millet, kodo millet, proso millet, and little millets [1].

The traditional rice cultivars have high nutrition than hybrid rice varieties [55]. They are a good source of minerals and vitamins such as niacin, thiamine, iron, riboflavin, vitamin D, calcium, and possess higher fiber. Furthermore, these cultivars possess several health benefits such as reducing the risk of developing type II diabetes, obesity, and cardiovascular diseases by lowering the glycemic and insulin responses [56].

Kumbhar et al. [57] report Tulshi tall, a landrace from Western Ghat zone of Maharastra, India, and Vikram, a landrace from Konkan region of Maharastra, showed moderate similarity in distinct differences in allelic combinations from other modern varieties. This report also suggests that landraces and local genotypes and Basmati rice of India have a long and independent history of evolution, which makes these indigenous species more distinct from the modern varieties. Landraces are unique and well adapted to agro-climatic conditions of its original area of cultivation. For example, Tulaipanji, an aromatic rice variety cultivated originally in cooler northern districts of West Bengal, India, lost its aroma when cultivated in the relatively warmer southern districts [58].

Jatu rice of Kullu valley, Himachal Pradesh, is prized for its aroma and taste. Matali and Lal Dhan of Himachal Pradesh are used for curing fever and reducing the elevated blood pressure. Kafalya is a popular red rice variety from the hills of Himachal Pradesh and Uttar Pradesh, used in treating leucorrhoea and complications from abortion [59]. In Karnataka, Kari Kagga and Atikaya are used to regulate body heat and also in preparation of a tonic whereas $\mathrm{Nee}$ lam Samba of Tamil Nadu is given to lactating mothers [60]. Maappillai Samba of Tamil Nadu is given to newly wedded groom to increase fertility [61]. Assam/North East parts of India use Assam black rice due to anti-cancer properties while its bran is used to soothe inflammation due to allergies, asthma, and other diseases. The varieties of Kerala such as Karinjan and Karimalakaran are rich in fiber and are known to reduce the risk of diabetes; Mundakan is consumed to increase the stamina; Vella chennellu and Chuvanna chennellu are consumed by pubescent, pregnant, and menopausal women, as it reduces problems associated with hormonal imbalances; Chuvanna kunjinelu is boiled with water and given to people who are suffering from epileptic fits; and Vellanavara and Rakthashali are consumed across India for its health benefits [62].

Sourirajan [63] reports on certain varieties of Tamil Nadu such as Kar arici and Vaikarai samba imparts strength, Karunguruvai acts as an antidiuretic, Puzhugu samba quenches intense thirst, Senchamba increases appetite, and Kodai samba reduces rheumatic pain. Jonga and Maharaji varieties of Bihar and Chhattisgarh are given to lactating mothers to increase lactation. Bora of Assam is used in the treatment of jaundice. Karhani of Chhattisgarh and Jharkhand is used as a tonic in the treatment of epilepsy. Layacha is consumed by pregnant women to prevent unborn children from contracting Laicha disease. Gudna rice is used to treat gastric ailments [64]. These are some of the benefits of the few reported varieties, while many remain undocumented and unexplored. Foods such as roti, idli, dosai, puttu, aval, dhokla, khaman, selroti, adai, sez, kulcha, naan, and kurdi; sweets such as adirasam, anarshe, and jalebi; snacks such as murukku, and vadai; and infant formulations are made from major cereals.

Millets are resistant to drought, pests, and diseases [65]. The growing season of millets is short, and the consumption of water for its cultivation is very less 
when compared to other cereals. Foods such as roti, dosai, and kuzh (porridge), snacks such as murukku, baby foods, ambali, wine, and health mix are made from millets. The polyphenols present in millets acts as antioxidant and boost immunity [66]. Lei et al. [67] report fermented millet products as a natural probiotic used for treating diarrhea in young children as the whole grain possesses prebiotic activity, increasing the population of good bacteria in the gut to promote digestion. Millets provide protection against obesity, diabetes, cardiovascular diseases, and cancer. Though millets possess various health benefits, the anti-nutrients present in millets weaken the absorption of nutrients. However, the antinutrients present in millets can be inactivated or reduced by soaking, cooking, germination, malting, removal of the seed coat, and fermentation, among others.

\section{The revival of indigenous crops}

From this research, it is evident that necessary measures should be carried out to conserve the indigenous species of the nation and also to carry knowledge to the future generations by reviving the crops back into cultivation. The government of India may initiate the acquisition and management of germplasm of all indigenous varieties by the Indian National Genebank at the National Bureau of Plant Genetic Resources (NBPGR), New Delhi. Furthermore, the primary factors that contribute to the revival of indigenous crops include the passion of farmers, administrative measures initiated by the stakeholders, and the marketing strategies of vendors. Additionally, the knowledge about the health benefits of indigenous crops may also prevent its extinction and ensure the availability of these foods in local markets and the methods of cooking for future generations [52].

Nevertheless, the revival of indigenous crops is possible only when all the stakeholders define and bring these crops under a special category similar to the one initiated in Kyoto, Japan. In Kyoto Prefecture, the "native varieties" are categorized into "Kyo-no-dento-yasai," and outside the prefecture, it is called "Brand-Kyo-yasai" [52]. Additionally, traditional food products of India may be collectively registered with the United Nations Educational, Scientific, and Cultural Organization's (UNESCO) Food Heritages as Intangible Cultural Heritage of $\mathrm{Hu}-$ manity similar to the registrations obtained for the washoku, a traditional dietary culture of Japan; the kimjang and kimchi of Republic of Korea; the Le repas gastronomique des Français (the gastronomic meal) of France; the Mediterranean diet; traditional Mexican foods; and the ceremonial keşkek of Turkey [68]. India may also adopt a geological indication (GI) for the traditional products like the one followed in the European Union and Japan $[69,70]$ to provide the farmers with better access to the willingness of their consumers to try the traditional food products [71].

\section{Advantages and challenges}

The benefits of indigenous crops over the introduced HYVs include (1) cultivation of indigenous crops can make agriculture more genetically diverse and sustainable, (2) consumption of domestically cultivated indigenous crops can reduce the carbon footprints [72] and imports, (3) the indigenous crops are highly adapted to the climatic conditions of the land, and (4) consumption of indigenous foods contribute to food diversity and enrichment of diet with micronutrients provides health benefits due to the interactions between the inherited genes and food nutrients [73].

However, there may be few challenges in reviving indigenous species, which may include (1) farmers' willingness in the propagation of indigenous varieties, (2) identifying the farmers with traditional knowledge of crop cultivation, (3) encouraging the farmers with large landholdings to cultivate indigenous crops, (4) awareness among the consumers and stakeholders about the ecological and health benefits of indigenous varieties, (5) support of the government to the farmers for the propagation of these crops in small and large scale, and (6) development of mechanization suitable for processing indigenous crops, as the existing machines are designed for the HYVs, and employing the same techniques for the processing of indigenous crops may lead to the loss of micronutrients and phytochemicals.

\section{Conclusion}

The measures discussed above may be initiated by the stakeholders to revive the indigenous crops, and it is imperative that food security must also ensure nutrition security of the nation. Thus, proper planning and intensive collaborative research work should be initiated by the stakeholders for the conservation of the traditional varieties and the inclusion of these varieties and practices into the food and nutrition security plans for the nation owing to their nutritional benefits.

\author{
Acknowledgements \\ The authors thank the anonymous reviewers for their valuable inputs and \\ comments. \\ Authors' contributions \\ All authors contributed equally to this study and write/revise the \\ manuscript. All authors read and approved the final manuscript. \\ Funding \\ Not applicable \\ Availability of data and materials \\ Not applicable \\ Competing interests \\ The authors declare that they have no competing interests.
}


Received: 3 January 2019 Accepted: 4 September 2019

Published online: 01 October 2019

\section{References}

1. Directorate of Economics and Statistics (DES), Ministry of Agriculture, India. 2014. https://eands.dacnet.nic.in/PDF/Glance-2016.pdf.

2. Food and Agriculture Organization of the United Nation. The state of food security and nutrition in the world. 2018. http://www.fao.org/3/i9553en/ i9553en.pdf.

3. International Institute for Population Sciences (IIPS) and ICF. National Family Health Survey (NFHS-4), 2015-16: India. Mumbai: IIPS; 2017. http://rchiips. org/nfhs/NFHS-4Reports/India.pdf.

4. Hall WF. Agriculture in India. Regional Analysis Division, Economic Research Service, United States Department of Agriculture, 1964. p. 13. https://archive. org/details/agricultureinind64hall.

5. US Department of Agriculture - Economic Research Service, Regional Analysis Division. The 1964 Far East, Communist China, Oceania Agricultural Situation: Supplement No. 4 to the 1964 World Agricultural Situation. 1963. p. 49-50. https://archive.org/details/1964fareastcommu74unit.

6. The Hindu. From 1,10,000 varieties of rice to only 6,000 now. India: The Hindu; 2012. http://www.thehindu.com/news/national/karnataka/from-11 0000-varieties-of-rice-to-only-6000-now/article3284453.ece

7. Conway G. The doubly green revolution: food for all in the 21 st century. London: Penguin Books; 1997.

8. Dalrymple DG. The adoption of high-yielding varieties in developing countries. Agric Hist. 1979;53:704-26.

9. Davies WP. An historical perspective from the green revolution to the gene revolution. Nutr Rev. 2003:61(6 Pt 2):S124-34.

10. Khush GS. Green revolution: preparing for the 21st century. Genome. 1999; 42:646-55.

11. Borlaug NE. Wheat breeding and its impact on world food supply. Proc Int Wheat Geneti Symp. 1968;3:1-36.

12. Rajaram S, Braun HJ. Half a century of international wheat breeding. Linnean. 2001;3:137-63.

13. Otero G, Pechlaner G. Latin American agriculture, food, and biotechnology: temperate dietary pattern adoption and unsustainability. In: Otero GA, editor. Food for the few: neoliberal globalism and biotechnology in Latin America. University of Texas Press: USA; 2008. p. 31-56.

14. Ehrlich PR. The population bomb. New York: Ballantine Books; 1968.

15. Myrdal G. Asian Drama: an inquiry into the poverty of nations. New York: Pantheon; 1968.

16. Lockwood B, Mukherjee PK, Shand RT. The High Yielding Varieties Programme in India, Part 1. Programme Evaluation Organization, Planning Commission of India and Department of Economics, and Research School of Pacific Studies, Australian National University, Canberra. 1971.

17. Baker CJ. Frogs and farmers: the Green Revolution in India, and its murky past. In: Bayliss-Smith T, Wanmali S, editors. Understanding Green Revolutions: Agrarian Change and Development Planning in South Asia. Cambridge: Cambridge University Press; 1984. p. 37-52.

18. Brown LR. Seeds of change. The Green Revolution and development in the 1970's. London: Pall Mall Press; 1969.

19. Parayil G. The green revolution in India: a case study of technological change. Technol Cult. 1992;33(4):737-56

20. Subramaniam C. The new strategy in Indian agriculture: the first decade and after. New Delhi: Vikas Publishing; 1979.

21. Chandler RF. The scientific basis for the increased yield capacity of rice and wheat. In: Poleman, Thomas T, Freebairn DK, editors. Food, population, and Employment: The Impact of the Green Revolution. New York: Praeger; 1973.

22. Dalrymple DG. Changes in wheat varieties and yields in the United States, 1919-1984. Agric Hist. 1988;62(4):20-36.

23. Lele U, Goldsmith AA. The development of National Research Capacity: India's experience with the Rockefeller Foundation and its significance for Africa. Econ Dev Cult Chang. 1989;37:305-44.

24. Bowonder B. Impact analysis of the green revolution in India. Technol Forecast Soc Chang. 1979;15:297-313.

25. Mohan R, Evenson R. The Indian agricultural research system. Econ Polit Wkly. 1973;8:A21-6.

26. Das RJ. Geographical unevenness of India's green revolution. J Contemp Asia. 1999;29(2):167-86.

27. Shiva $V$. The violence of the green revolution: third world agriculture, ecology and politics. 2nd ed. Zed Books Ltd. London, UK; 1993.
28. Newman B. A BITTER HARVEST: Farmer suicide and the unforeseen social, environmental and economic impacts of the Green Revolution in Punjab, India. 2007. https://pdfs.semanticscholar.org/dacb/5aeaa16704a5e50b3b246 9368d57e760f227.pdf?.ga=2.106311680.2094921914.1568185786-49843292 8.1568185786.

29. Department of Fertilizers and Department of Agriculture, Cooperation \& Farmers Welfare (DAC\&FW). India. 2017 http://agricoop.nic.in/sites/default/ files/Krishi\%20AR\%202017-18-1\%20for\%20web.pdf.

30. Singh RB. Environmental consequences of agricultural development: a case study from the green revolution state of Haryana, India. Agric Ecosyst Environ. 2000:82(1-3):97-103.

31. Ashraf AM, Lokanadan S. A review of rice landraces in India and its inherent medicinal values -the nutritive food values for future. Int J Curr Microbiol App Sci. 2017;6(12):348-35

32. Abhilash PC, Singh N. Pesticide use and application: an Indian scenario. J Hazard Mater. 2009;165(1-3):1-12.

33. Rekha, Naik SN, Prasad R. Pesticide residue in organic and conventional food-risk analysis. J Chem Health Saf. 2006;13:12-9. https://www. sciencedirect.com/science/article/abs/pii/S1074909805000262.

34. Yadav IC, Devi NL, Syed JH, Cheng Z, Li J, Zhang G, Jones KC. Current status of persistent organic pesticides residues in air, water, and soil, and their possible effect on neighboring countries: a comprehensive review of India. Sci Total Environ. 2015;51(1):123-37.

35. Agricultural Statistics Division, Third Advance Estimates of Production of Food grains for 2016-17, Department of Agriculture, Cooperation and Farmers welfare, India. 2017. https://eands.dacnet.nic.in/Advance_Estimate/3 rd_Adv_Estimates2016-17_Eng.pdf.

36. Singh KP, Mishra A, Mishra HN. Fuzzy analysis of sensory attributes of bread prepared from millet-based composite flours. LWT-Food Sci Technol. 2012; 48:276-82.

37. Devi GN, Padmavathi G, Babu VR, Waghray K. Proximate nutritional evaluation of Rice (Oryza sativa L.). J Rice Res. 2015;8(1):23-32.

38. Hulse JH, Laing EM, Pearson OE. Sorghum and the millets: their composition and nutritive value. New York: Academic Press; 1980

39. Juliano $\mathrm{BO}$, Bechtel $\mathrm{DB}$. The rice grain and its gross composition. In: Juliano BO, editor. Rice chemistry and technology. American Association of Cereal Chemists: Eagan, MN, USA; 1985. p. 17-57.

40. Longvah $T$, Ananthan $R$, Bhaskarachary $K$, Venkaiah K. Proximate principles and dietary fibre. In: Indian Food Composition Tables, National Institute of Nutrition, Department of Health Research, Ministry of Health and Family Welfare, Government of India, Hyderabad. 2017.

41. Pedersen B, Eggum BO. The influence of milling on the nutritive value of flour from cereal grains. Plant Food Hum Nutr. 1983;33:267-78.

42. Saikia S, Dutta H, Saikia D, Mahanta CL. Quality characterisation and estimation of phytochemicals content and antioxidant capacity of aromatic pigmented and non-pigmented rice varieties. Food Res Int. 2012:46(1):334-40

43. Sompong R, Siebenhandl-Ehn S, Linsberger-Martin G, Berghofer E. Physicochemical and antioxidative properties of red and black rice varieties from Thailand, China and Sri Lanka. Food Chem. 2011;124:132-40.

44. United States Department of Agriculture/Human Nutrition Information Service (USDA/HNIS). Composition of foods: cereal grains and pasta. Agriculture Handbook No. 8-20. Washington, DC; 1984

45. National Research Council. United States-Canadian Tables of Feed Composition: Nutritional Data for United States and Canadian Feeds. Third Revision. Washington, DC: The National Academies Press; 1982. https://doi. org/10.17226/1713.

46. Food and Agriculture Organization of the United Nations (FAO). Sorghum and millets in human nutrition. FAO, Rome, Italy; 1995.

47. National Nutrition Monitoring Bureau (NNMB). Prevalence of micronutrient deficiencies. Technical report No.22, National Institute of Nutrition, ICMR; 2003

48. INSA. Micro-nutrient security for India - priorities for research and action. India: Indian National Science Academy; 2011. http://insaindia.res.in/ download\%20form/Micronutrient_final_with_cover.pdf

49. Dalar A, Uzun Y, Turker M, Mukemre M, Konczak I. Health attributes of ethnic vegetables consumed in the eastern Anatolia region of Turkey: antioxidant and enzyme-inhibitory properties. J Ethn Foods. 2016:3:142-9.

50. Kohsaka R, Matsuoka H, Uchiyama Y. Capturing the relationships between local foods and residents: a case in the Noto region, Japan. J Ethn Foods. 2016:3:86-92. 
51. Mohammed J, Seleshi S, Nega F, Lee M. Revisit to Ethiopian traditional barley-based food. J Ethn Foods. 2016;3:135-41.

52. Nakamura T, Nakamura Y, Sasaki A, Fujii M, Shirota K, Mimura Y, Okamoto S. Protection of Kyo-yasai (heirloom vegetables in Kyoto) from extinction: a case of Sabaka-daikon (Japan's heirloom white radish, Raphanus sativus) in Maizuru, Japan. J Ethn Foods. 2017:4(2):103-9.

53. Sasaki A, Nakamura Y, Kobayashi Y, Aoi W, Nakamura T, Shirota K, Suetome N, Fukui M, Shigeta T, Matsuo T, Okamoto S, Park EY, Sato K. A new strategy to protect Katsura-uri (Japan's heirloom pickling melon, Cucumis melo var. conomon) from extinction. J Ethn Foods. 2017:4(1):44-50.

54. Richharia RH, Govindasamy S. Rices of India. Karjat: Academy of Development Science; 1990.

55. Bhat FM, Riar CS. Health benefits of traditional Rice varieties of temperate regions. Med Aromatic Plants. 2015;4(3):198.

56. Umadevi M, Pushpa R, Sampathkumar KP, Bhowmik D. Rice-traditional medicinal plant. India J Pharmacogn Phytochem. 2012;1(1):6-12.

57. Kumbhar SD, Kulwal PL, Patil JV, Sarawate CD, Gaikwad AP, Jadhav AS Genetic diversity and population structure in landraces and improved rice varieties from India. Rice Sci. 2015;22(3):99-107.

58. Deb D. Folk rice varieties of West Bengal: agronomic and morphological characteristics. In: Research Foundation for Science, Technology and Ecology, New Delhi; 2000.

59. Ahuja U, Ahuja SC, Chaudhary N, Thakrar R. Red rices-past, present, and future. Asian Agri-History. 2007;11(4):291-304.

60. Arumugasamy S, Jayashankar N, Subramanian K, Sridhar S, Vijayalakshmi K. Indigenous rice varieties. Centre for Indian Knowledge System, Chennai, Tamil Nadu, India; 2001. p.74.

61. Sulochana S, Singaravadivel K. A study on phytochemical evaluation of traditional rice variety of Tamil Nadu - 'Maappillai Samba' by GC-MS. Int J Pharma Biosci. 2015;6(3):606-11.

62. Nagarajan S. Indigenous rice varieties make a comeback. The Hindu, India. 2018. http://www.thehindu.com/life-and-style/food/thanals-save-our-rice-isreviving-indigenous-rice-varieties/article22420554.ece

63. Sourirajan M. 'Pathartha Gunapadam - Palporul vilakkam (in Tamil)'. Saraswati Mahal Press, Thanjavur, Tamil Nadu, India; 2000. p. 322-328.

64. Rahman S, Sharma MP, Sahai S. Nutritional and medicinal values of some indigenous rice varieties. Indian J Tradit Knowl. 2006:5(4):454-8.

65. Devi PB, Vijayabharathi R, Sathyabama S, Malleshi NG, Priyadarisini VB. Health benefits of finger millet (Eleusine coracana L.) polyphenols and dietary Fiber: a review. J. Food Sci Technol. 2014;51(6):1021-40.

66. Chandrasekara A, Shahidi F. Content of insoluble bound phenolics in millets and their contribution to antioxidant capacity. J Agric Food Chem. 2010;58:6706-14.

67. Lei V, Friis H, Michaelsen KF. Spontaneously fermented millet product as a natural probiotic treatment for diarrhea in young children: an intervention study in northern Ghana. Int J Food Microbiol. 2006;1 10:246-53.

68. Kohsaka R. The myth of washoku: a twisted discourse on the "uniqueness" of national food heritages. J Ethn Foods. 2017;4(2):66-71.

69. Gugerell K, Uchiyama Y, Kieninger PR, Penker M, Kajima S, Kohsaka R. Do historical production practices and culinary heritages really matter? Food with protected geographical indications in Japan and Austria. J Ethn Foods. 2017:4(2):118-25.

70. Kajima S, Tanaka Y, Uchiyama Y. Japanese sake and tea as place-based products: a comparison of regional certifications of globally important agricultural heritage systems, geopark, biosphere reserves, and geographical indication at product level certification. J Ethn Foods. 2017:4(2):80-7.

71. Sylvander B, Isla A, Wallet F. Under what conditions geographical indications protection schemes can be considered as public goods for sustainable development? Territorial governance, Physica-Verlag, Heidelberg 2011:185-202.

72. Smith A, Watkiss P, Tweddle G, McKinnon A, Browne M, Hunt A, Treleven C, Nash C, Cross S. The validity of food miles as an indicator of sustainable development. Final report produced for Defra - report ED50254. AEA Technology Environment: London, UK; 2005

73. Neeha VS, Kinth P. Nutrigenomics research: a review. J Food Sci Technol. 2013:50(3):415-28.

74. Department of Agriculture, Cooperation and Farmers Welfare, India. 2017. http://agricoop.nic.in/sites/default/files/pocketbook_0.pdf

\section{Publisher's Note}

Springer Nature remains neutral with regard to jurisdictional claims in published maps and institutional affiliations.

\section{Ready to submit your research? Choose BMC and benefit from:}

- fast, convenient online submission

- thorough peer review by experienced researchers in your field

- rapid publication on acceptance

- support for research data, including large and complex data types

- gold Open Access which fosters wider collaboration and increased citations

- maximum visibility for your research: over $100 \mathrm{M}$ website views per year

At BMC, research is always in progress.

Learn more biomedcentral.com/submissions 